\title{
Erratum: Identification of the gene responsible for methylmalonic aciduria and homocystinuria, cblC type
}

Jordan P Lerner-Ellis, Jamie C Tirone, Peter D Pawelek, Carole Doré, Janet L Atkinson, David Watkins, Chantal F Morel, T Mary Fujiwara, Emily Moras, Angela R Hosack, Gail V Dunbar, Hana Antonicka, Vince Forgetta, C Melissa Dobson, Daniel Leclerc, Roy A Gravel, Eric A Shoubridge, James W Coulton, Pierre Lepage, Johanna M Rommens, Kenneth Morgan \& David S Rosenblatt

Nat. Genet. 38, 93-100 (2006); published online 27 November 2005; corrected after print 30 June 2006

In the version of this article initially published, the numbering of references $22-29$ in the reference list was incorrect. The correct numbering is

as follows:

22. Watkins, D. Cobalamin metabolism in methionine-dependent human tumour and leukemia cell lines. Clin. Invest. Med. 21, 151-158 (1998).

23. Watkins, D., Matiaszuk, N. \& Rosenblatt, D.S. Complementation studies in the cblA class of inborn error of cobalamin metabolism: evidence for interallelic complementation and for a new complementation class (cblH). J. Med. Genet. 37, 510-513 (2000).

24. Ewing, B., Hillier, L., Wendl, M.C. \& Green, P. Base-calling of automated sequencer traces using Phred I. Accuracy assesment. Genome Res. 8, 175-185 (1998).

25. Gordon, D., Abajian, C. \& Green, P. Consed: a graphical tool for sequence finishing. Genome Res. 8, 195-202 (1998).

26. Miller, A.D. \& Buttimore, C. Redesign of retrovirus packaging cell lines to avoid recombination leading to helper virus production. Mol. Cell Biol. 6, 2895-2902 (1986).

27. Yao, J. \& Shoubridge, E.A. Expression and functional analysis of SURF1 in Leigh syndrome patients with cytochrome C oxidase deficiency. Hum. Mol. Genet. 8, 2541-2549 (1999).

The error has been corrected in the PDF version of this article.

\section{Corrigendum: PLA2G6, encoding a phospholipase $A_{2}$, is mutated in} neurodegenerative disorders with high brain iron

Neil V Morgan, Shawn K Westaway, Jenny E V Morton, Allison Gregory, Paul Gissen, Scott Sonek, Hakan Cangul, Jason Coryell,

Natalie Canham, Nardo Nardocci, Giovanna Zorzi, Shanaz Pasha, Diana Rodriguez, Isabelle Desguerre, Amar Mubaidin, Enrico Bertini,

Richard C Trembath, Alessandro Simonati, Carolyn Schanen, Colin A Johnson, Barbara Levinson, C Geoffrey Woods, Beth Wilmot,

Patricia Kramer, Jane Gitschier, Eamonn R Maher \& Susan J Hayflick

Nat. Genet. 38, 752-754 (2006); published online 18 June 2006; corrected after print 17 July 2006

In the version of this article initially published, the authors neglected to acknowledge sample contributions. Samples were obtained from the "Cell line and DNA bank from patients affected by genetic diseases” collection at the Giannina Gaslini Institute (http://www.gaslini.org/labdppm.htm) supported by Italian Telethon grants (project \#GTF04002). This error has been corrected in the PDF version of the article. 